\title{
Modeling of Water Fluxes and Budget in Nam Co Basin during 1979-2013
}

\author{
KAI TONG \\ Key Laboratory of Environment Change and Resources Use in Beibu Gulf, Ministry of Education, Nanning Normal \\ University, Nanning, and Key Laboratory of Tibetan Environment Changes and Land Surface Processes, Institute of Tibetan \\ Plateau Research, Chinese Academy of Sciences, Beijing, China \\ FENGGE SU \\ Key Laboratory of Tibetan Environment Changes and Land Surface Processes, Institute of Tibetan Plateau Research, \\ Chinese Academy of Sciences, and CAS Center for Excellence in Tibetan Plateau Earth Sciences, and University of Chinese \\ Academy of Sciences, Beijing, China

\section{CHUNHONG Li} \\ Key Laboratory of Tibetan Environment Changes and Land Surface Processes, Institute of Tibetan Plateau Research, \\ Chinese Academy of Sciences, and University of Chinese Academy of Sciences, Beijing, China
}

(Manuscript received 20 June 2019, in final form 17 March 2020)

\begin{abstract}
In this study, we established a hydrologic modeling framework over the Nam Co Lake basin by linking a glacier-melt scheme with a physically based, distributed land surface hydrologic model, and a heat-balance model was used for water surface evaporation. Hydrologic processes including evapotranspiration from land regions, runoff from both glacierized and nonglacierized areas, and lake surface evaporation were continuously modeled for 1979-2013, and then lake level changes were reconstructed. Rainfall runoff, snowmelt runoff, and glacier runoff contributed $59 \%, 28 \%$, and $13 \%$ of total runoff, respectively. For the high-altitude region, runoff was mostly generated from glaciers. The lake had a positive water budget in most of the years with an average lake level depth of $128.8 \mathrm{~mm}$, resulting in a total rise of approximately $4.5 \mathrm{~m}$. Precipitation and precipitation-induced runoff were the main water supplies and played a dominant role in lake growth. Although the glacier runoff only contributed $13 \%$ of the total runoff, it played an important role in controlling the water level. The rising temperature led to increasing evaporation in two ways: one was providing an energy source for evaporation, and the second was extending the ice-free period. This mitigated the recent expansion of the lake, but on the other hand, it led to increasing glacier runoff into the lake. Hence, the rising temperature had two diametrically opposed effects on lake water balance.
\end{abstract}

\section{Introduction}

The Tibetan Plateau (TP) is called "the Third Pole" (Qiu 2008) and "the Asian water tower" (Immerzeel et al. 2010). The large number and widely distributed area of lakes is one of the TP's prominent features (Ma et al. 2011), and there are more than 1200 lakes with areas over $1 \mathrm{~km}^{2}$, with a total area of approximately $47000 \mathrm{~km}^{2}$ (Zhang et al. 2014a). Since the 1970s, most of lakes have been expanding (Lei et al. 2013, 2014), except for lakes located in the southern plateau (Ye et al. 2008; Zhang et al. 2014b).

Corresponding author: Fengge Su, fgsu@itpcas.ac.cn
Nam Co is a large endorheic lake in the central plateau. Since the 1970s, the lake area has expanded by approximately $80 \mathrm{~km}^{2}$, the lake level has risen by $4.7 \mathrm{~m}$, and the lake water storage has increased by $9.3 \mathrm{Gt}$ (Lei et al. 2013). The lake responds sensitively to climate change and influences significantly on climate change (Dai et al. 2018). There are debates on the primary factors causing the dramatic changes in Nam Co Lake in recent decades. Liu et al. (2010) suggested that the Nam Co Lake expansion was related to permafrost degradation and climate change. Zhu et al. (2010) concluded that precipitation was the major water resource of Nam Co Lake, while glaciers played an important role in the lake enlargement. Study for the Nam Co Lake basin and five other lake basins in the central TP for the period of 
1976-2010 suggested that the main causes of the lake expansions were decreased lake evaporation, increased precipitation, and runoff (Lei et al. 2013).

In the Nam Co Lake basin, there are no sufficient observations for hydrologic processes, and hydrologic simulations are required to estimate the water balance. Gao et al. (2012) investigated the application of J2000 hydrologic model in the Qugaqie (a typical glacierized catchment in the Nam Co basin). Their extended work investigated glacier mass balance, runoff, and water balance by integrating snow and glacier models into the Jena Adaptable Modelling System (JAMS)/J2K hydrologic model during 2006-08 (Gao et al. 2015). In the Qugaqie basin, the glacier meltwater contributed $41 \%-$ $58 \%$ to the total basin runoff, while in the Zhadang subbasin it contributed $66 \%-78 \%$ (Gao et al. 2012, 2015). In the Qugaqie basin, Li et al. (2014) investigated glacier mass balance and runoff with the GSSHA model and a glacier-melt model during 2006-11. The glacial runoff contributed $15 \%$ of the total runoff, while in the upstream portion with large percentage of glacierized area, the contribution increased to $46 \%$. Zhang et al. (2016) showed that glacier runoff contributed $64 \%$ of the total basin discharge in the Zhadang subbasin during 2012-14 by coupling a glacier-melt model with the Distributed Hydrology Soil Vegetation Model (DHSVM). Modeling work from Krause et al. (2010) in the entire Nam Co basin replaced the lake level changes for 2006-08 and showed that glacier runoff seems to be the most important component for explaining the increasing amount of lake water over the past 50 years. A 10-yr-long (2001-10) modeling study in four lakes (including Nam Co Lake) in the southern-central TP indicated that the glacier-melt contribution to the total basin runoff volume played a less important role than precipitation-induced runoff in nonglacierized land areas (Biskop et al. 2016). In Nam Co Lake, long-term (1980-2010) changes in the water budget and lake level were simulated using a dynamic water balance model by Wu et al. (2014), and glacier melt, rainfallrunoff, precipitation and evaporation on the lake, and lake percolation contributed to $56.6 \%, 104.7 \%, 41.7 \%,-80.9 \%$, and $-22.2 \%$, respectively.

Climate changes greatly affect the hydrologic cycle over the TP, and lakes are sensitive indicators of climate change in this region (Shi 1990; Lu et al. 2005). A long-term comprehensive and systematic hydrologic study for a lake basin is still lacking. The modeling studies mentioned above in the Nam Co Lake basin either focused on small typical glacierized basins (e.g., the Qugaqie basin and Zhadang subbasin) or used conceptual models to investigate hydrologic processes on the scale of the entire lake basin. Physically based, distributed hydrologic models allow for better understanding of the hydrologic processes in the watershed, for example, spatial variations of runoff and evapotranspiration over vast land regions. In this study, we established a hydrologic modeling framework over the Nam Co Lake basin by linking a glacier-melt scheme with a physically based, distributed land surface hydrologic model, and a heatbalance model was used for water surface evaporation. Runoff from both the glacierized and nonglacierized areas, evapotranspiration from the land areas, and evaporation on the lake surface were continuously modeled during 1979-2013, and then the lake level changes were reconstructed. This work aims to comprehensively investigate the hydrologic processes and water balance terms in Nam Co Lake, and better understand the hydrologic response of closed lakes to climate changes in the TP.

\section{Study region}

Nam Co is located on the north foot of the Nyainqêntanglha Mountains, central TP, with a basin elevation between 4723 and $6744 \mathrm{~m}$ (Fig. 1). The lake had an area of $2021 \mathrm{~km}^{2}$ in 2010 (Lei et al. 2013) and is currently the second largest inland lake after Siling Co Lake in Tibet. The drainage area is approximately $10610 \mathrm{~km}^{2}$, and the replenishment coefficient is 5.53 (Wang et al. 2009). In this basin, the land cover is composed of open shrubland and grassland according to the Global Land Cover Classification Database (Hansen et al. 2000). The soils are clay and sandy (silty) soil below $20 \mathrm{~cm}$, and meadow soils up to a depth of $20 \mathrm{~cm}$ (Tian et al. 2009). The Indian monsoon affects the Nam Co Lake basin from June to September, and most of the annual precipitation falls during this period. In contrast, the westerly controls the basin during the dry season and lasts from November to May (You et al. 2007; Chen et al. 2009). There are 68 subbasins (area over $5 \mathrm{~km}^{2}$ ) with runoff inflows into the lake (Fig. 1). All land areas were divided into three subregions (regions I, II, and III) for hydrologic model calibration (Fig. 1). The three subregions have different climatology and topography. The region I has lower elevation and higher temperature; region II consists of a number of small catchments and glacier cover in the mountain area; region III is located in the northeast and has the highest precipitation. Each region has a stream gauge station in the boundary.

\section{Data and methodology}

\section{a. Data}

We obtained the Shuttle Radar Topography Mission (SRTM) data with a spatial resolution of $90 \mathrm{~m}$ (Jarvis et al. 2008). The SRTM data were used to create digital 


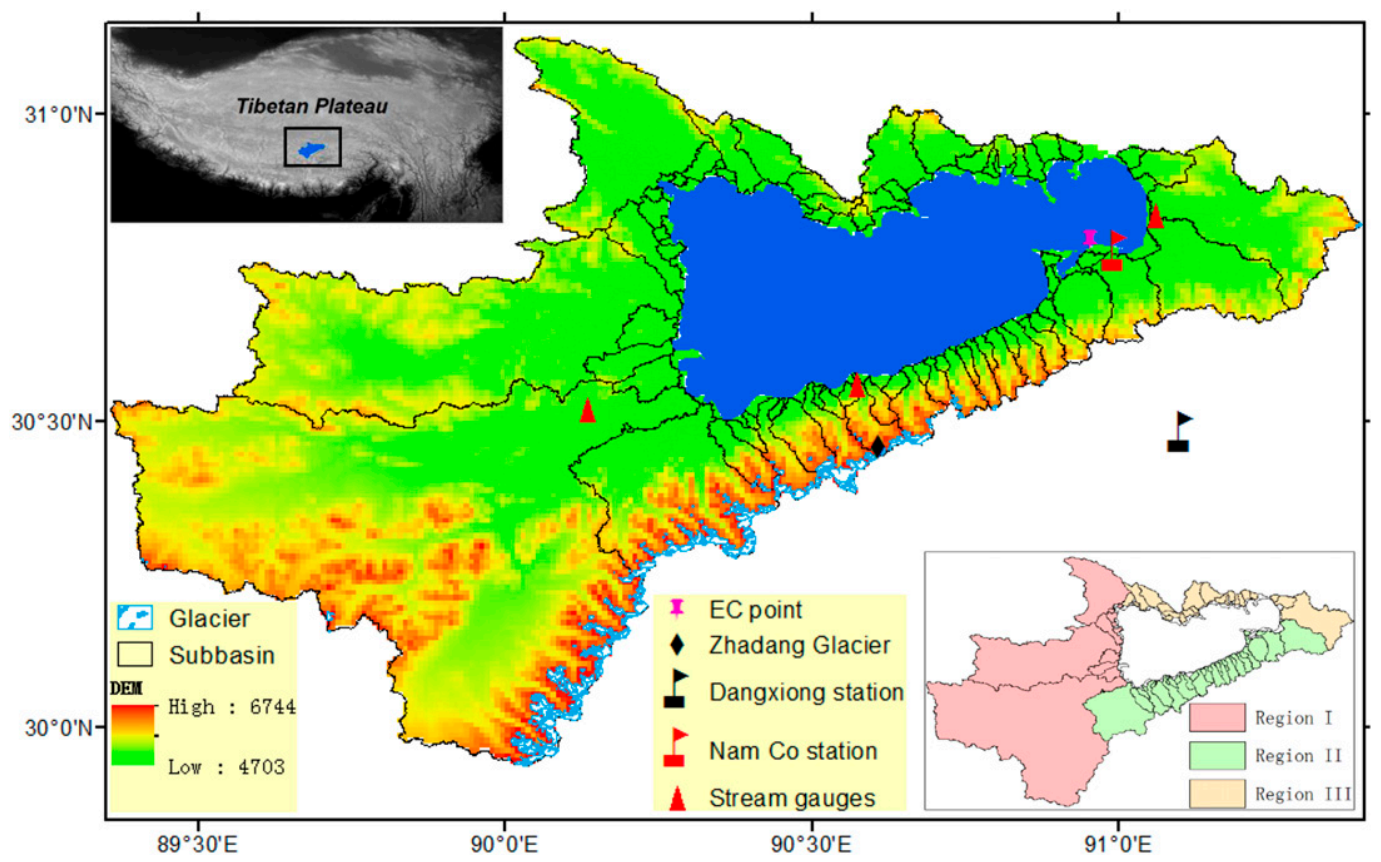

FIG. 1. Location and topography of the Nam Co Lake basin and the distribution of hydrometeorological stations.

river networks and delineate basin boundaries by using the Hydrology Tools in ArcGIS. Then, the 90-m grid cell was upscaled to $1 \mathrm{~km}$ for the setup and running of the hydrologic model.

Monthly streamflow data for the Angqu, Qugaqie, and Niyaqu Rivers for 2006-08 were provided by the Third Pole Environment Database. Landsat MSS images were used to extract the glacier distribution. The total glacier areas in 1976, 1988, and 2000 were 200.7, 195.4, and $182.6 \mathrm{~km}^{2}$, respectively (Table 1 ). The three extracted glacier distributions were used as inputs of a glacier-melt scheme for glacier streamflow simulations for three periods: $1979-88,1989-2000$, and 2001-13, respectively. The lake surface evaporation data for 2012-13 were from Lu et al. (2017) and were obtained by using an eddy covariance (EC) instrument. The EC instrument was installed at the eastern part of the lake (Fig. 1).

The ITPCAS forcing dataset (Yang and He 2018; He et al. 2020), developed by the Institute of Tibetan
Plateau Research, Chinese Academy of Sciences, is available from 1979 to 2015 with a spatiotemporal resolution of $0.1^{\circ}$ and $3 \mathrm{~h}$. The ITPCAS dataset includes precipitation, temperature, wind speed, air pressure, downward longwave/shortwave radiation, and specific humidity. Chen et al. (2011) found that the ITPCAS data are more accurate than the Global Land Data Assimilation System (GLDAS) forcing data when used to drive the revised Noah model. By comparison with observations from the Global Energy and Water Cycle Experiment Asian Monsoon Experiment-Tibet Plateau Experiment (GAME-Tibet) and the Coordinated Enhanced Observing Period Asian-Australian Monsoon Project Experiments-Tibet (CAMP-Tibet) at point scales, the ITPCAS estimates has superiority than other precipitation datasets in the TP (He 2010). The dataset has been successfully used in the Siling Co Lake basin nearby (Tong et al. 2016). In this study, the ITPCAS dataset for 19792013 were used in the Nam Co Lake basin. To maintain consistency with our hydrologic model setup over the

TABLE 1. Glacier area in the Nam Co Lake basin from Landsat for different periods.

\begin{tabular}{|c|c|c|}
\hline Year & Landsat image & Glacier area $\left(\mathrm{km}^{2}\right)$ \\
\hline 1976 & $\begin{array}{l}\text { LM02_L1TP_148039_19761217_01_T2 } \\
\text { LM02_L1TP_149039_19761218_01_T2 }\end{array}$ & 200.7 \\
\hline 1988 & $\begin{array}{l}\text { LT05_L1TP_138039_19880601_01_T1 } \\
\text { LT05_L1TP_139039_19880608_01_T1 }\end{array}$ & 195.4 \\
\hline 2000 & $\begin{array}{l}\text { LE07_L1TP_138039_20001117_01_T1 } \\
\text { LE07_L1TP_139039_20001108_01_T1 }\end{array}$ & 182.6 \\
\hline
\end{tabular}




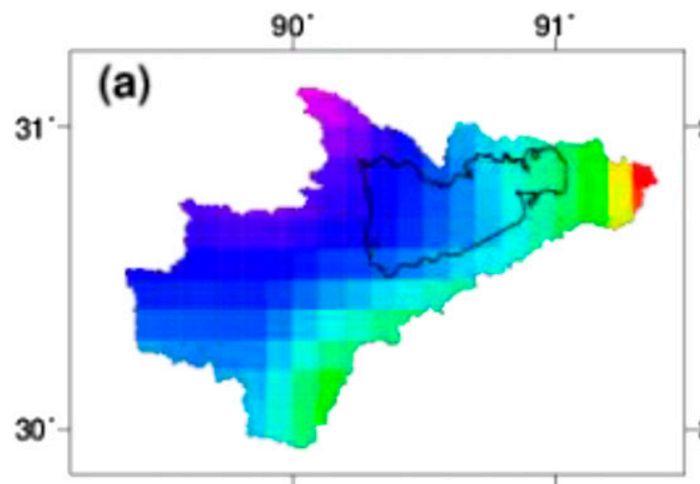

$350 \quad 375400425450475500 \quad 525 \quad 550$

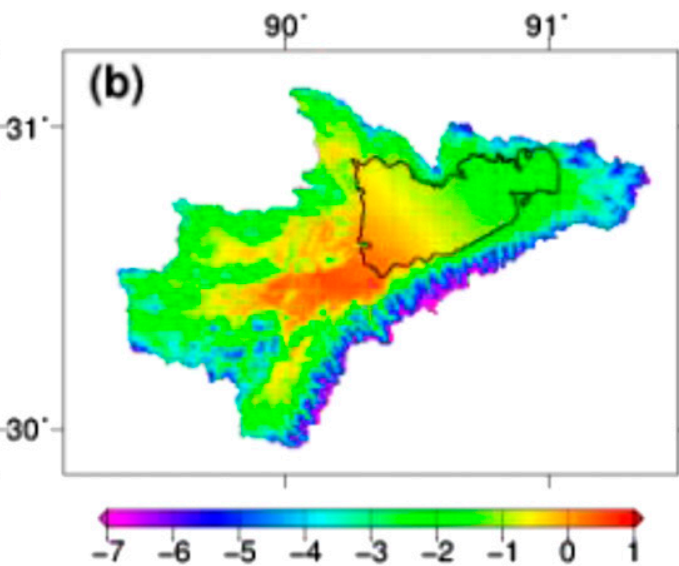

FIG. 2. Spatial distribution of the (a) mean annual precipitation $(\mathrm{mm})$ and $(\mathrm{b})$ temperature $\left({ }^{\circ} \mathrm{C}\right)$ over the Nam Co Lake basin during 1979-2013.

Nam Co Lake basin, the ITPCAS data were regridded to 1-km grids using the nearest neighbor approach.

Figure 2 shows the spatial distribution of the average annual (1979-2013) precipitation and temperature from the ITPCAS data over the Nam Co Lake basin. The annual precipitation exhibited a northwest to southeast gradient, ranging from $350 \mathrm{~mm}$ in the northwest to over $550 \mathrm{~mm}$ in the southeast (Fig. 2a). The spatial pattern of temperature was consistent with that of the topography, with the lowest temperature (approximately $-7^{\circ} \mathrm{C}$ ) from the mountain areas with the highest elevation and the highest temperature (approximately $1^{\circ} \mathrm{C}$ ) from the center with the lowest elevation (Fig. 2b).

\section{b. Methodology}

\section{1) HYDROLOGIC MODEL AND PARAMETERS}

The Variable Infiltration Capacity (VIC) model (Liang et al. 1994, 1996) was used to simulate runoff and evapotranspiration over the Nam Co Lake basin in this study. It is a physically based, distributed hydrologic model, and simulates the physical exchange of energy and water among atmosphere, vegetation and soil over a grid mesh and solves both water balances and surface energy flux. The VIC model has capacity to simulate hydrology in cold region due to a two-layer energy balance snow model (Storck and Lettenmaier 1999; Cherkauer and Lettenmaier 1999) and a frozen soil/permafrost algorithm (Cherkauer and Lettenmaier 1999, 2003). Here, a modeling framework was setup at a resolution of $1 \mathrm{~km} \times 1 \mathrm{~km}$ over the entire Nam Co Lake basin. The Harmonized World Soil Database (FAO/IIASA/ISRIC/ISSCAS/JRC 2012) is constructed by FAO and IIASA and contains over 16000 different soil mapping units. Here, we chose this dataset to extract the soil information. The Global Land Cover product was constructed by the
University of Maryland (Hansen et al. 2000) using data for 1992-93 from the Advanced Very High Resolution Radiometer (AVHRR), which contains water and 13 land cover classifications. In this study, we used the product with $1-\mathrm{km}$ spatial resolution for vegetation types in the VIC model. And the leaf area index (LAI) derived from the global LAI database of Myneni et al. (1997) was also employed for the hydrologic model. In this study, a spinup has been done when running the VIC model.

A simple degree-day glacier-melt algorithm (Hock 1999, 2003) was used to simulate runoff from glacierized areas in this study. The degree-day model and the VIC model were linked to simulate the hydrologic processes for both the glacierized and nonglacierized areas in the basin. In a grid cell, the total runoff from both the glacierized areas and nonglacierized areas can be calculated as:

$$
R_{i}=f \times M_{i}+(1-f) \times R_{\mathrm{vic}},
$$

where $f$ is the glacier area fraction in grid $i ; M_{i}$ and $R_{\mathrm{vic}}$ are the meltwater from the glacierized areas and the runoff from the nonglacierized area. A routing scheme (Lohmann et al. 1996, 1998) was used to route the total runoff $R_{i}$ in each cell to basin outlets through a channel network.

In the modeling work, model parameters need to be determined: 1) degree-day factors for both ice $\left(\mathrm{DDF}_{\text {ice }}\right)$ and snow $\left(\mathrm{DDF}_{\text {snow }}\right)$ and 2$)$ parameters in the VIC model. A degree-day factor value $\left(\mathrm{DDF}_{\text {snow }}\right.$ of $5.3 \mathrm{~mm}^{\circ} \mathrm{C}^{-1} \mathrm{day}^{-1}$ and $\mathrm{DDF}_{\text {ice }}$ of $9.2 \mathrm{~mm}^{\circ} \mathrm{C}^{-1} \mathrm{day}^{-1}$, Table 2) based on Wu et al. (2010) in the Zhadang Glacier (Fig. 1) were used for the entire basin. For the VIC model, the parameters most often calibrated include the infiltration parameter $\left(b_{\text {infilt }}\right)$, the depth of the first and second soil layers (d1, d2), and the base flow parameters $\left(W_{s}, D_{s}, D_{\text {smax }}\right)$. 
TABLE 2. Degree-day factors used in the degree-day model and parameters used in the VIC model for the Nam Co Lake basin.

\begin{tabular}{|c|c|c|c|c|}
\hline \multicolumn{5}{|c|}{ Degree-day model } \\
\hline & $\operatorname{DDF}_{\text {ice }}\left(\mathrm{mm}^{\circ} \mathrm{C}^{-1} \mathrm{day}^{-1}\right)$ & & 9.2 & \\
\hline \multicolumn{5}{|c|}{ VIC model } \\
\hline Parameter & Physical meaning & Region I & Region II & Region III \\
\hline$b_{\text {infilt }}$ & Variable infiltration curve parameter & 0.01 & 0.01 & 0.01 \\
\hline$D_{s}$ & $\begin{array}{l}\text { Fraction of } D_{\text {smax }} \text { where nonlinear } \\
\text { base flow begins }\end{array}$ & 0.05 & 0.02 & 0.1 \\
\hline$D_{\text {smax }}$ & $\begin{array}{l}\text { Fraction of maximum soil moisture where } \\
\text { nonlinear base flow occurs }\end{array}$ & 10 & 10 & 10 \\
\hline$W_{s}$ & Maximum velocity of base flow & 0.9 & 0.9 & 0.9 \\
\hline $\mathrm{d} 1$ & $\begin{array}{l}\text { Thickness of the first soil moisture } \\
\text { layer }(\mathrm{m})\end{array}$ & 0.1 & 0.1 & 0.1 \\
\hline $\mathrm{d} 2$ & $\begin{array}{l}\text { Thickness of the second soil moisture } \\
\text { layer }(\mathrm{m})\end{array}$ & 2.5 & 2.5 & 2.0 \\
\hline
\end{tabular}

The monthly streamflow data at the outlets of the Angqu, Qugaqie and Niyaqu (Fig. 1) for 2006-08 were collected for the VIC model calibration (not shown). Table 2 shows the final model parameters over the Nam Co Lake basin. A long-term runoff inflow to Nam Co Lake was simulated with the calibrated model for the period of 1979-2013. In the future, more observed streamflow data could be collected, which would help to improve the representation of the model parameters.

\section{2) LAKE SURFACE EVAPORATION MODEL}

As Nam Co is a closed lake with no outflow, lake surface evaporation is the only way that water may leave. In this study, we adapted a one-layer water model based on heat balance equations (Kondo and Kuwagata 1992; Xu et al. 2009) to estimate the evaporation.

The heat balance equation is written as

$$
R^{\downarrow}-G_{0}=\varepsilon \sigma T_{w}^{4}+H+l E,
$$

where $R^{\downarrow}$ is the input radiation flux, $G_{0}$ is the heat flux of conduction to the water, and $T_{w}$ is the calculated water (or ice) temperature, $E$ is the evaporation of the lake surface, $l E$ and $H$ are the latent and sensible heat fluxes, respectively.

As located in a high altitude $(>4700 \mathrm{~m})$ with a cold climate condition, Nam Co freezes during the cold season. Ke et al. (2013) analyzed ice phenology of Nam Co Lake based on remote sensing data, and we adopted the results of frozen period (Fig. 13a). During the frozen lake period, we used a simple method (Kojima 1979) for estimating the sublimation.

The Dangxiong station is the nearest national meteorological station for Nam Co Lake (approximately 30-km distance, Fig. 1), and the meteorological data including daily air temperature, sunshine duration, wind speed, relative humidity, and air pressure for 1979-2013 were used for the lake evaporation calculations. We also collected meteorological data for 2006-08 from the Nam Co station (Fig. 1), which is located near the lake. The data from the Dangxiong station were adjusted based on the meteorological data from the Nam Co station. The temporal variations patterns of the two datasets presented great similarity with high correlation coefficients $(0.972,0.585,0.838$, and 0.962 for air temperature, wind speed, relative humidity, and air pressure, respectively), and several linear correction functions were used to correct the data of the Dangxiong station and as follows:

$$
\begin{aligned}
& \text { air temperature: } T_{\text {cor }}=T_{\text {Dangxiong }}-3.51, \\
& \quad \text { wind speed: } \mathrm{WS}_{\text {cor }}=\mathrm{WS}_{\text {Dangxiong }} \times 1.62,
\end{aligned}
$$

relative humidity: $\mathrm{RH}_{\text {cor }}=\mathrm{RH}_{\text {Dangxiong }} \times 1.12$, and

$$
\text { air pressure: } \mathrm{AP}_{\text {cor }}=\mathrm{AP}_{\text {Dangxiong }} \times 0.95 \text {, }
$$

where $T_{\text {cor }}, \mathrm{WS}_{\text {cor }}, \mathrm{RH}_{\text {cor }}$, and $\mathrm{AP}_{\text {cor }}$ are corrected air temperature, wind speed, relative humidity, and air pressure, respectively. And the sunshine duration data were adopted from the Dangxiong station without adjustment due to almost the same latitudes.

The daily observed lake surface evaporation data (Fig. 1) for August-November 2012 and June-November 2013 adopted from Lu et al. (2017) were used for model calibration. Compared to the observed evaporation, the simulation got a moderate performance at daily time scales with an overall relative bias $\left(R_{\text {bias }}\right)$ of $-1 \%$, a NashSutcliffe efficiency coefficient (NSE) of 0.201 , a correlation coefficient $(r)$ of 0.641 , and a root-mean-square 


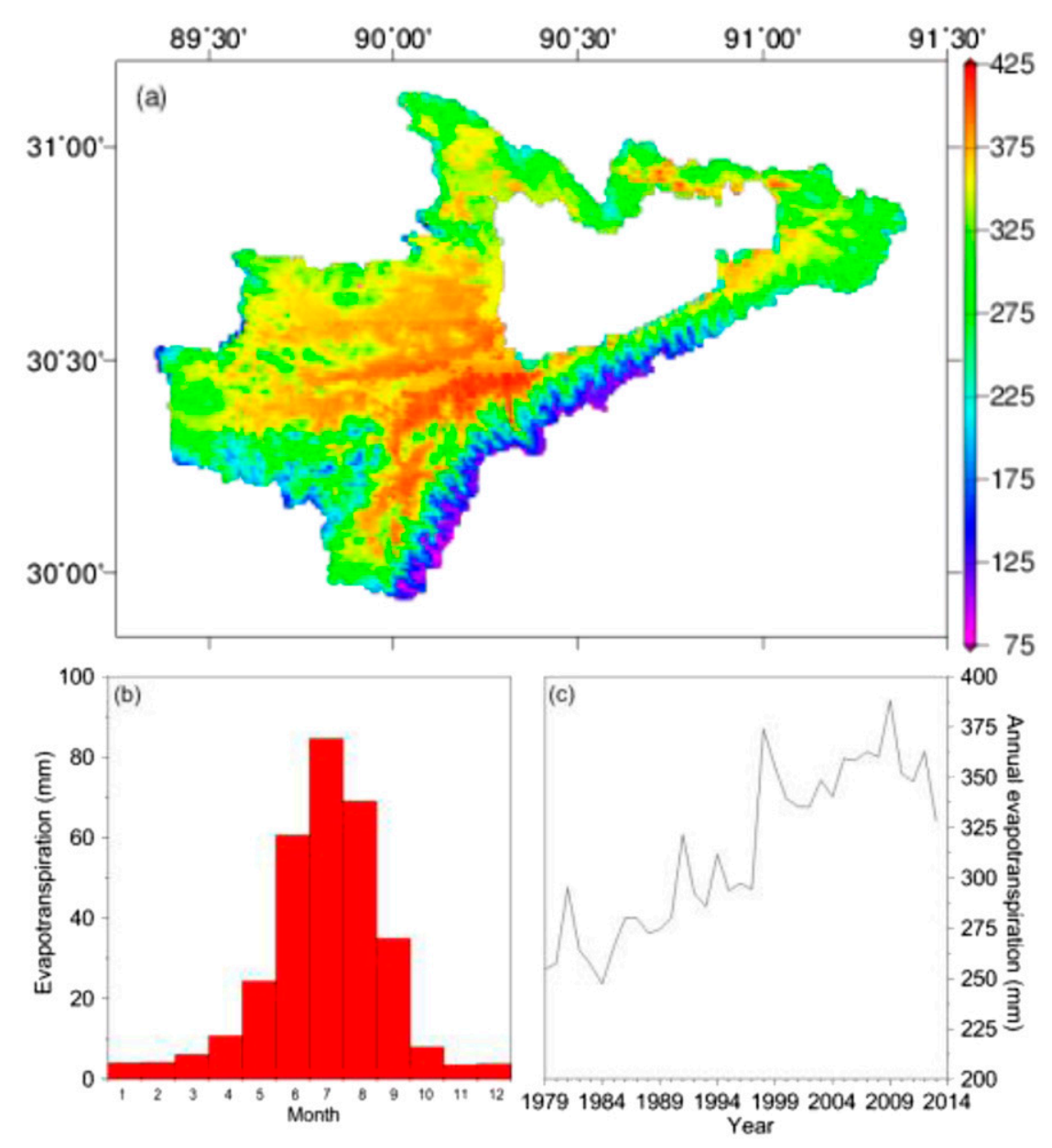

FIG. 3. Evapotranspiration over the Nam Co Lake basin during 1979-2013: (a) spatial distribution of the mean annual evapotranspiration $\left(\mathrm{mm} \mathrm{yr}^{-1}\right)$, (b) seasonal cycle of basin-averaged evapotranspiration, and (c) annual time series of basin-averaged evapotranspiration.

error (RMSE) of 0.923 . The evaporation on the lake surface was continuously modeled during 1979-2013 by the one-layer water model.

\section{3) LAKE WATER BALANCE COMPUTATION}

In a closed lake, the water balance can be mathematically expressed as

$$
\Delta V=P_{\text {lake }}-E_{\text {lake }}+R_{\text {land }},
$$

where $\Delta V$ is the change in the lake storage; $P_{\text {lake }}$ and $E_{\text {lake }}$ are precipitation and evaporation; and $R_{\text {land }}$ is runoff inflows to the lake. Conversion of lake volumes to lake level changes is based on the equation

$$
\Delta V=\frac{1}{3} \times\left(S_{1}+S_{2}+\sqrt{S_{1} \times S_{2}}\right) \times h,
$$

where $S_{1}$ and $S_{2}$ are lake areas at two stages, respectively; and $h$ is the lake level change. The lake area data were adopted from Lei et al. (2013), and a linear interpolation was used to get continues annual lake area time series. Then the interpolated annual lake area data were used in Eq. (8) to convert lake volumes to lake level changes.

\section{Results}

\section{a. Spatial pattern of evapotranspiration and runoff}

In this section, we analyzed the spatial pattern of evapotranspiration and runoff in the Nam Co Lake basin. Figure 3 shows the evapotranspiration over the land regions of the basin from the calibrated VIC model during 1979-2013. The mean annual evapotranspiration ranged from 75 to $425 \mathrm{~mm}$, with the lowest appearing in the southeastern high mountain regions and the largest appearing in the center (Fig. 3a), generally consistent with the spatial distribution of temperature within the basin (Fig. 2b). The seasonal cycle and annual time series of the basin-averaged evapotranspiration were 


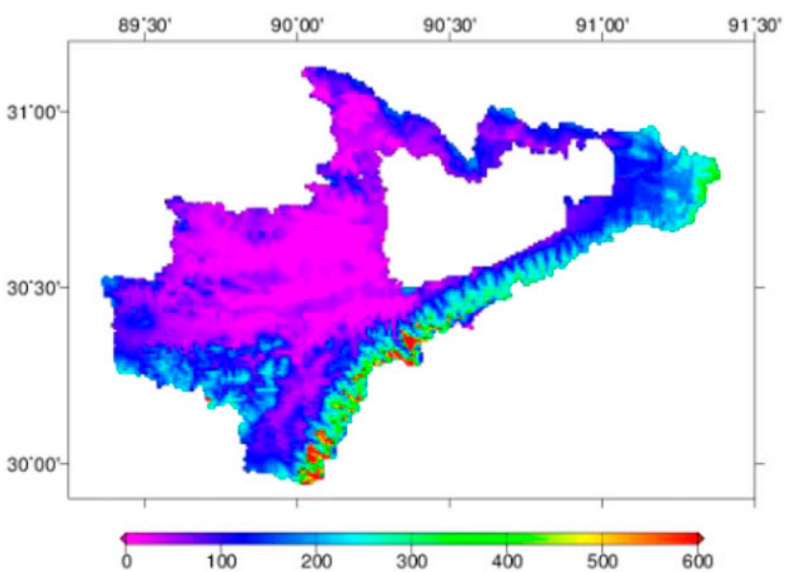

FIG. 4. Spatial distribution of the mean annual runoff $\left(\mathrm{mm} \mathrm{yr}^{-1}\right)$ over the Nam Co Lake basin during 1979-2013.

also included in the figure (Figs. 3b,c). Approximately $80 \%$ of the mean annual evapotranspiration occurred in summer months, with the peak occurring in July. Less than $10 \%$ of the annual total evapotranspiration occurred in the winter. The annual basin-averaged evapotranspiration showed a dynamic increasing trend consistent with rapid warming (Fig. 3c). The land regions of the basin had a mean annual evapotranspiration of $313.5 \mathrm{~mm}$ during 1979-2013.

Figure 4 shows the simulated runoff over the land regions of the Nam Co Lake basin during 1979-2013. The mean annual runoff exhibited substantial spatial heterogeneity. The mountain region in the southeastern

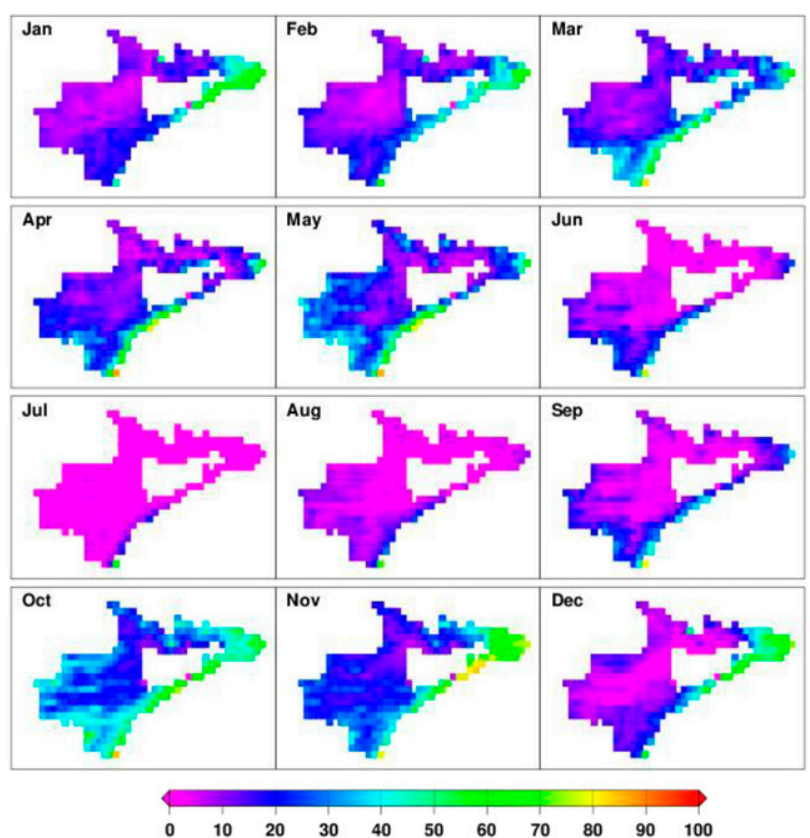

basin was the main runoff-producing area, where annual runoff ranged from 300 to $600 \mathrm{~mm}$, while annual runoff was less than $50 \mathrm{~mm}$ in the northwestern basin. The highest runoff in the southeastern high mountain region was due to plentiful precipitation (Fig. 2a) and less evapotranspiration (Fig. 3a). Moreover, glaciers in the mountains generated meltwater in the warm season (Fig. 7). The land regions of the basin had a mean annual runoff of $107.6 \mathrm{~mm}$ during 1979-2013.

\section{b. Snow cover extent}

Besides glacier distribution, TP is covered by amounts of snow. TP snow cover has impact on East Asian atmospheric circulation at medium-range time scales $(\mathrm{Li}$ et al. 2018). In the TP, snowmelt runoff plays an important role in the total runoff (Zhang et al. 2013). The simulated snow cover extent in the Nam Co basin was compared with estimates from the Moderate-Resolution Imaging Spectroradiometer (MODIS) data. The MOD10C2 data with a resolution of $0.05^{\circ}$ and 8 days for 2001-13 from the National Snow and Ice Data Center of the NASA were employed. Figure 5 (left panel) shows the spatial fields of the monthly mean Snow Cover Fraction (SCF, \%) from MODIS during 2001-13. High SCF concentrated on the southeastern high mountain areas. In contrast, the center of the basin with the lowest elevation had relatively less snow cover. The simulated SCF (Fig. 5, right panel) showed consistent spatial variations with the MODIS data; however, there were some obvious differences between the model simulated and

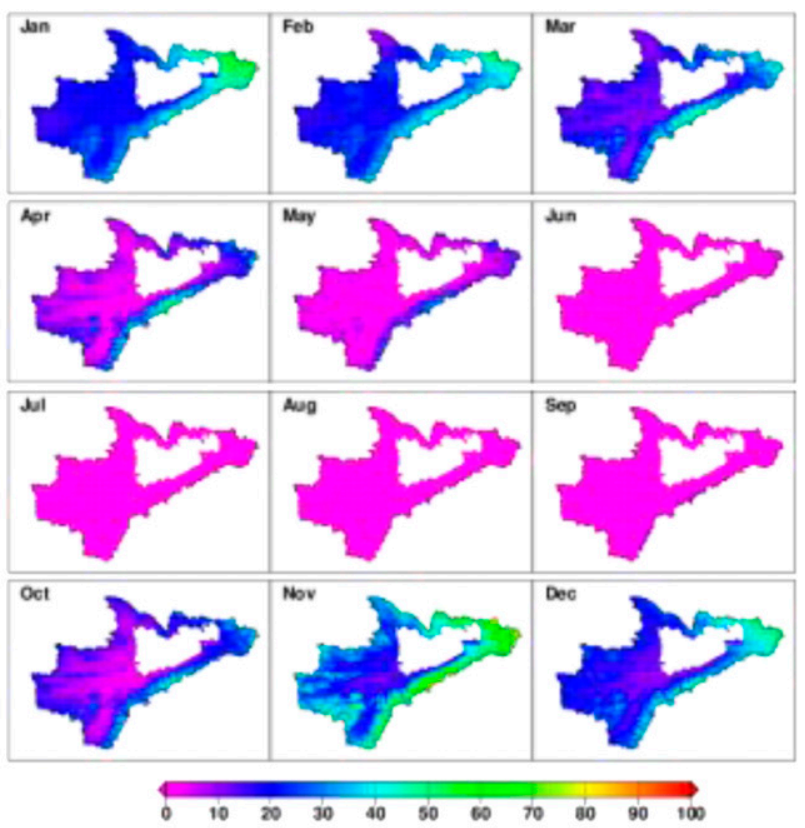

FIG. 5. Monthly mean snow cover fraction (SCF; \%) from (left) MODIS and (right) the VIC model during 2001-13. 

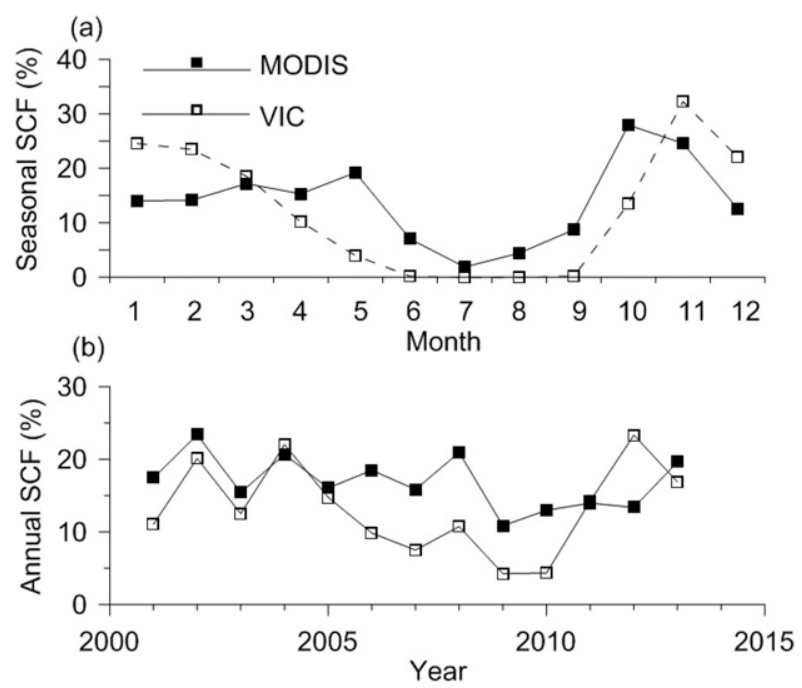

FIG. 6. (a) Monthly mean and (b) annual time series snow cover fraction (SCF; \%) from MODIS and the VIC model during 2001-13.

the remote sensing estimate during the warm season in the high mountain areas. There was almost no snow cover in the model simulated during the warm season (Fig. 5, left, and Fig. 6a). However, MODIS showed some snow cover in the high mountain areas; this might be due to the mismeasurement of ice cover in the high mountain areas by MODIS. Contrast to warm season, the modeled SCF was much larger than MODIS SCF in winter season (November to February). For the annual time series of the SCF (Fig. 6b), the model simulations and MODIS showed consistent variations before 2005, then differed after that. The VIC model setup in this study had a spatial resolution of $1 \mathrm{~km}$ and was run at a 3-h time step, while MODIS had a coarser resolution of $0.05^{\circ}$ and 8 days, which might also bring bias.

\section{c. Runoff components}

Figure 7 shows the seasonal distribution of each runoff component and total runoff from simulation during 1979-2013. Due to the monsoon water vapor transport, approximately $83 \%$ of the mean annual precipitation fell in summer, while less than $5 \%$ occurred in winter. The rainfall runoff and snowmelt runoff contributed $59 \%$ and $28 \%$ of the total runoff $\left(9.42 \times 10^{8} \mathrm{~m}^{3} \mathrm{yr}^{-1}\right)$, respectively. The glacier runoff mostly occurred in summer, with the peak occurring in July. The glacier runoff only contributed $13 \%$ of the total runoff (Fig. 7).

Figure 8 shows the percentage of three runoff components and the total runoff at altitude bands. For the four bands $(<5000,5000-5500,5500-6000,>6000 \mathrm{~m})$, the total runoff values were $62.0,113.5,351.8$ and $364.1 \mathrm{~mm}$, respectively. In the region with altitudes less

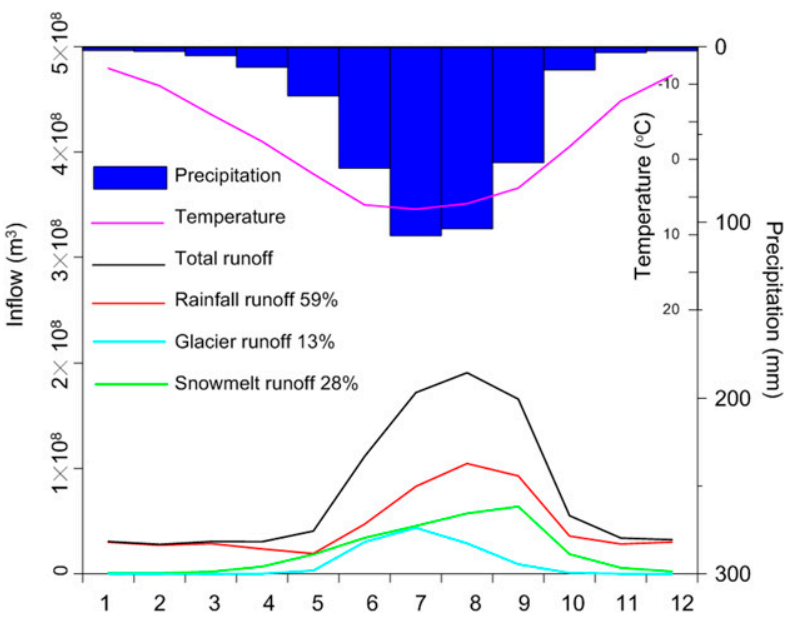

FIG. 7. Simulated seasonal distribution of total runoff, rainfall runoff, snowmelt runoff, and glacier runoff inflow to Nam Co Lake during 1979-2013. The seasonal cycles of basin-averaged (land area) precipitation and temperature are also included.

than $5000 \mathrm{~m}$ covering $44.7 \%$ of the basin area, rainfall runoff and snowmelt runoff contributed $68.3 \%$ and $31.7 \%$, respectively, to the total runoff. The $5000-5500-\mathrm{m}$ band had the largest area percent $(47.1 \%)$ among the four bands. In this band, rainfall and snowmelt runoff accounted for $64.2 \%$ and $34.4 \%$, respectively, while glacier runoff only accounted for $1.4 \%$. The $5500-6000-\mathrm{m}$ band accounted for only $7.9 \%$ of the total basin area, and glacier runoff $(43.7 \%)$ was greater than both rainfall runoff $(42.3 \%)$ and snowmelt runoff $(14.0 \%)$. For the region with altitudes $>6000 \mathrm{~m}, 81.5 \%$ of the total runoff was from glaciers, and snowmelt and rainfall runoff together accounting for only $18.5 \%$. The results suggested that rainfall runoff was the main water source in the basin, while for the high-altitude region (5500-6000, >6000 m), runoff was mostly generated from glaciers.

Figure 9 shows annual time series of runoff during 1979-2013. The annual total runoff had an increasing trend during 1979-2004, while the trend reversed after 2005 , accompanied by the variation pattern of basin-average (land area) precipitation. The mean annual total runoff was $9.42 \times 10^{8} \mathrm{~m}^{3}$ during 1979 2013. The variation pattern of the rainfall runoff was fairly similar to that of the total runoff, with a mean annual of $5.65 \times 10^{8} \mathrm{~m}^{3}$. According to the degree-day glacier-melt algorithm, once the degree-day factors (DDFs) are fixed, the variation of glacier runoff is highly associated with that of temperatures in the melt season. The amount of glacier runoff inflow $\left(1.22 \times 10^{8} \mathrm{~m}^{3} \mathrm{yr}^{-1}\right)$ was much less than the rainfall runoff inflows, and it exhibited an increasing trend of $5.08 \times 10^{6} \mathrm{~m}^{3} \mathrm{yr}^{-1}(P<0.01)$ throughout the study 


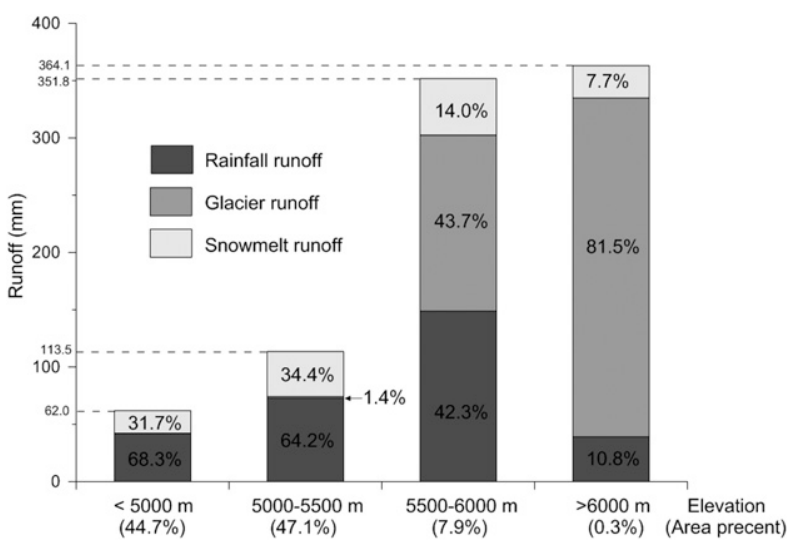

FIG. 8. Percentage of three runoff components (rainfall, glacier, and snowmelt runoff) at four elevation bands with altitudes $<5000$, $5000-5500,5500-6000$, and $>6000 \mathrm{~m}$.

period, along with the rising temperatures. In contrast to glacier runoff, snowmelt runoff showed a decreasing trend of $-3.06 \times 10^{6} \mathrm{~m}^{3} \mathrm{yr}^{-1}(P<0.05)$.

\section{d. Lake water balance and level reconstruction}

Figure 10 shows the annual time series of the lake water balance during 1979-2013, including evaporation and precipitation on the lake surface, total runoff inflow, and net budgets. The annual precipitation had a mean value of $410.5 \mathrm{~mm}$ with no significant increasing trend during 1979-2013. The total runoff [transformed to depth according to Eq. (8)] had an increasing trend during 1979-2004, while it showed a decreasing trend after 2004. The calculated mean annual evaporation was $758.3 \mathrm{~mm}$ for the entire study period of 1979-2013. The lake had a positive water budget in most of the years (Fig. 10). The overall pattern of the water budgets was similar to that of runoff inflow, and the good correspondence suggested that runoff inflow played an important role in lake growth.

After accumulating the net water budget year by year, the variation in the lake levels can be obtained during 1979-2013, as shown in Fig. 11. We used two lake level change data: data from Lei et al. (2013) covered the whole study period, and data from the Hydroweb (http:// hydroweb.theia-land.fr/hydroweb/) provided much higher density data with a shorter period of 1995-2013. The calculated changes in the lake level generally followed those of the observations. In the simulation, the lake level rose by $4.5 \mathrm{~m}$ during 1979-2013, which was comparable to the result (4.7 $\mathrm{m}$ for 1970-2010) of Lei et al. (2013). There existed slight difference between the simulation and the Hydroweb observations. According to our calculation, the lake level rose by $2.75 \mathrm{~m}$, while $3.96 \mathrm{~m}$ (from 4721.62 to $4724.58 \mathrm{~m}$ ) by satellite-based observation (Fig. 11). The lake level did not show a linear increasing trend for the entire period of 1979-2013 and even slightly declined after 2004 (Fig. 11). The decrease in lake expansion after 2004 is mainly due to runoff decrease, which is mainly a result of precipitation decrease. The consistency between the simulated and observed lake level changes can be an implication of a well-constrained model performance.

A hypothetical ice-free scenario in the lake basin was evaluated. The hypothetical ice-free scenario means the glacier area fraction $f$ is 0 , and Eq. (1) will change to be $R_{i}=R_{\text {vic }}$. In this case, the total runoff inflow to the lake $\left[R_{\text {land }}\right.$ in Eq. (7)] is entirely from the VIC model consisting of rainfall and snowmelt runoff. In Fig. 11, the simulated lake level change without glacier runoff (red line with hollow circle) was obtained by accumulating the yearly net water budget with Eq. (7). Before 2005, the lake level dramatically rose by $3.5 \mathrm{~m}$. While after that, the simulated lake level would not rise but showed an obvious descend trend. To investigate impact of glacier runoff to lake level change, we convert glacier runoff inflow to lake level changes based on Eq. (8). The annual lake level changes induced by glacier runoff inflow range from 14 to $163 \mathrm{~mm}$, and the accumulated lake level changes could reach to $2155 \mathrm{~mm}$ in 2013 relative to the 1979. Although the glacier runoff only contributed $13 \%$ of the total runoff, it played an important role in controlling the water level.

\section{Discussion}

There are approximately 46300 glaciers in the TP and surrounding regions, with a total area of approximately $59400 \mathrm{~km}^{2}$ and volume of approximately $5600 \mathrm{~km}^{3}$ (Shi 2005). Under climatic warming, most of these glaciers are shrinking, with obvious implications for rivers and lakes (Shi 2001; Yao et al. 2004, $2007,2010)$. Studies on some typical glacier-fed lakes inferred that the lake expansions were caused by an increase in the glacial meltwater induced by rising temperatures (Lei et al. 2012; Meng et al. 2012; Liao et al. 2013).

Studies have indicated that glaciers in the Nyainqêntanglha Range shrank in past decades under climatic warming (Kang et al. 2007; Bolch et al. 2010; Yao et al. 2012). Nam Co is a glacier-fed lake located in the north foot of the Nyainqêntanglha Range, and its water storage has increased since the 1970s (Lei et al. 2013). There are debates on the primary factors causing the dramatic changes in Nam Co Lake in recent decades (Zhu et al. 2010; Lei et al. 2013). Song et al. (2015) noted that whether glacier melt is the main factor for dramatic lake changes depends on the ratio of the meltwater to the total water supply. In this study, we simulated 


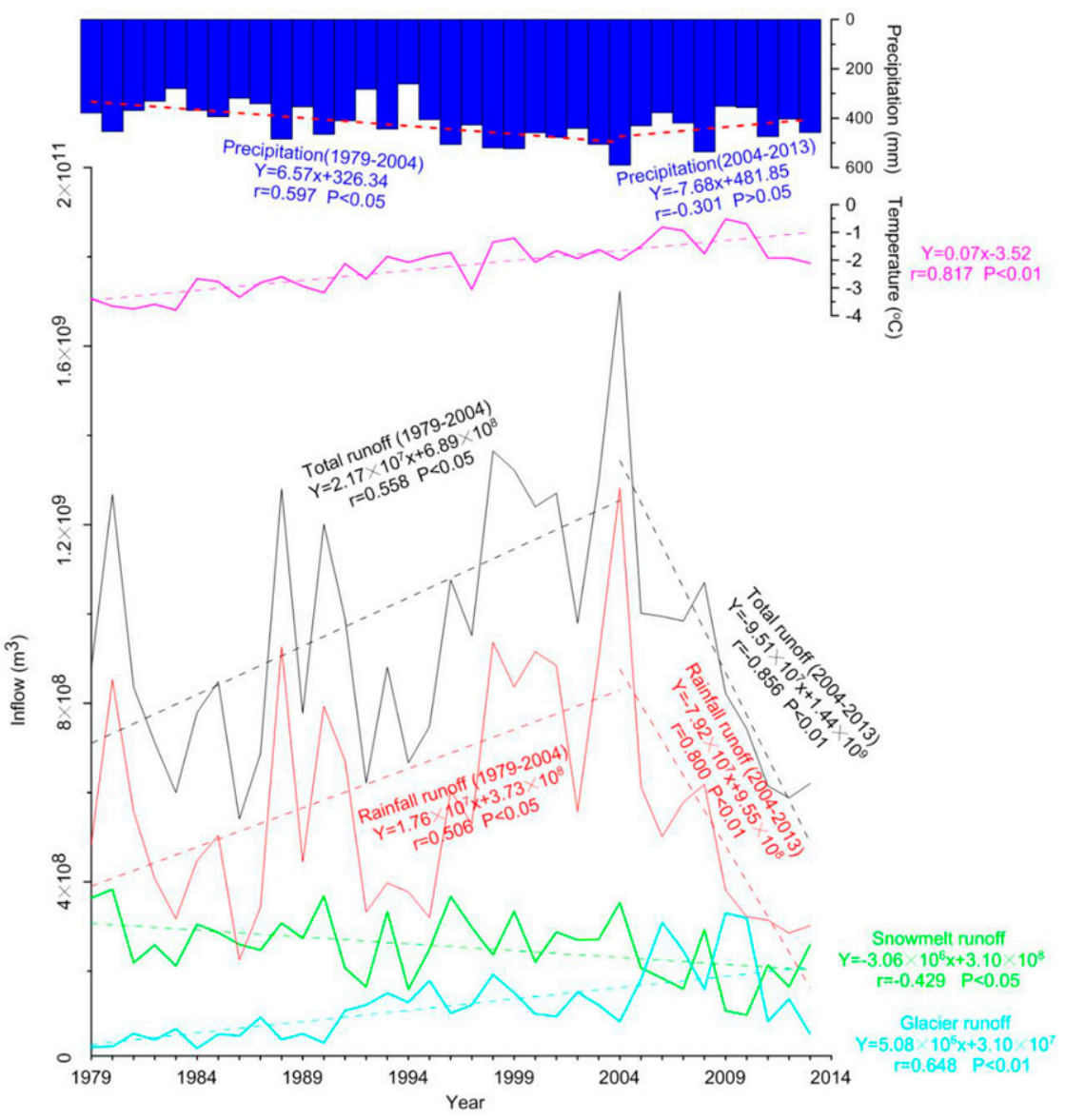

FIG. 9. Annual time series of simulated total runoff, rainfall runoff, snowmelt runoff, and glacier runoff inflows to Nam Co Lake during 1979-2013. The annual time series of basinaveraged (land area) precipitation are also included.

runoff from glacierized areas in the catchment. The glacier runoff showed a significant increasing trend under climatic warming, but the amount was small and contributed only $13 \%$ of the total runoff inflows to Nam Co Lake during 1979-2013 (Figs. 7 and 9). According to a recent study by Gao et al. (2015), glacial-melt runoff contributed almost half of the total runoff in the Qugaqie basin in 2006-08, which is a typical glacierized subbasin in the Nam Co watershed with $8.4 \%$ glacierized coverage. Compared to the Qugaqie basin, the entire Nam Co Lake basin has less glacierized coverage (less than $2 \%$ ). Therefore, the contribution of glacier runoff in the entire Nam Co Lake basin was much smaller than that in the Qugaqie basin. Study conducted by Biskop et al. (2016) in the entire Nam Co basin showed that the contribution of glacier runoff to total basin runoff volume was $19 \%$ during 2001-10, which was larger than our results of $13 \%$ for the period of 1979-2013. For a comparison, we calculated the glacier runoff contribution for 2001-10 and got a value of $18.4 \%$, which was close to $19 \%$ in Biskop et al. (2016), suggesting that the contribution of glacier runoff to total basin flows is increasing with the warmer climate in the 2000s.

In this study, we simulated each water component of the lake and reconstructed the lake level changes from 1979 to 2013. The annual time series of the simulated glacier runoff inflows showed a substantial increasing trend $\left(5.08 \times 10^{6} \mathrm{~m}^{3} \mathrm{yr}^{-1}\right)$ with rising temperatures (Fig. 9). According to our modeling, the lake level rose by $4.5 \mathrm{~m}$, although it did not show a linear increasing trend for the entire period of 1979-2013; it even slightly declined after 2005 (Fig. 11). The lake level change was not consistent with the temporal variation of the glacier runoff inflows. Song et al. (2015) compared the time series of Nam Co Lake water level variations during the premonsoon to autumn with the mass balance of Zhadang Glacier during 2003-11 and found that the two showed inverse relationships. Glacier water might not be the driving 


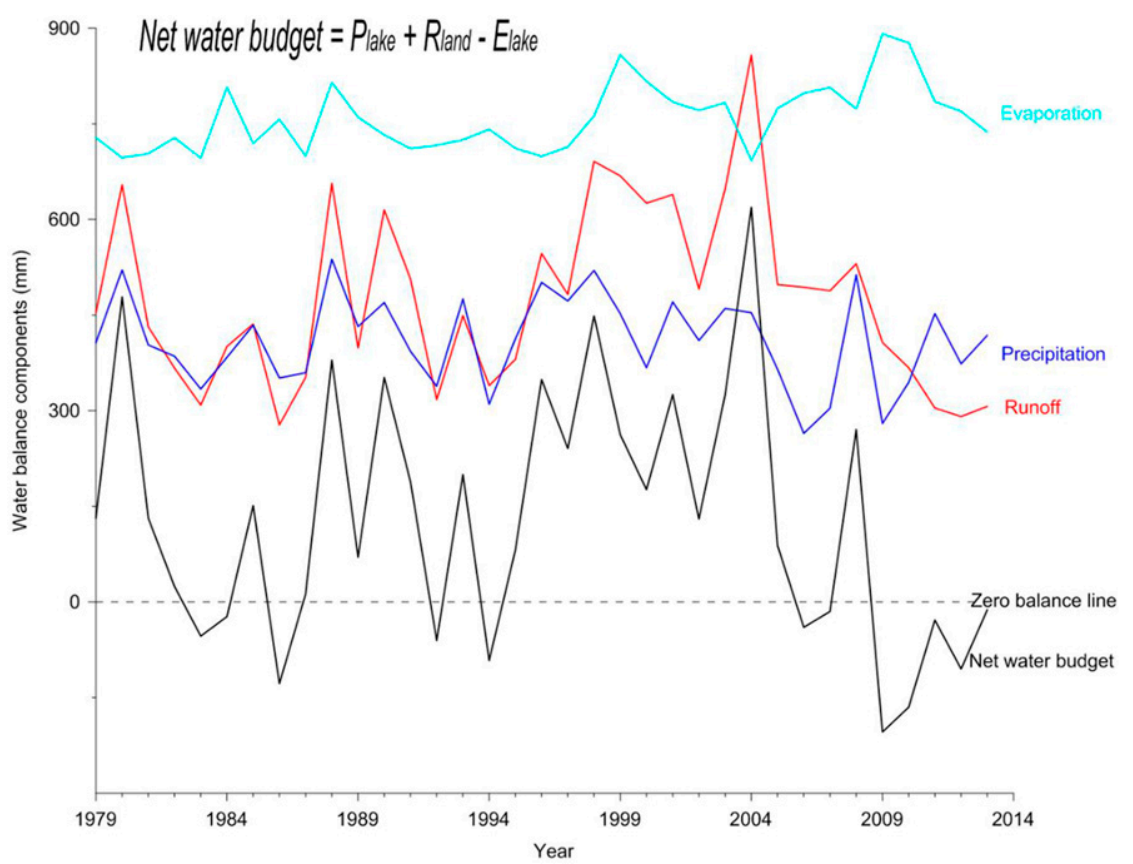

FIG. 10. Time series of each water balance component for Nam Co Lake during 1979-2013. Total runoff inflow has been transformed to depth $(\mathrm{mm})$ on the lake surface.

force of the dramatic changes in Nam Co Lake in recent decades.

According to modeling, from 1979 to 2013, the mean annual total runoff, precipitation and evaporation were $476.6,410.5$, and $758.3 \mathrm{~mm}$, respectively. The lake had a positive net water budget in most of the years, with an average lake level depth of $128.8 \mathrm{~mm}$ during 1979-2013, resulting in a total rise of approximately $4.5 \mathrm{~m}$. Precipitation-induced runoff (rainfall runoff and snowmelt runoff) contributed $87 \%$ of the total runoff; therefore, precipitation and precipitationinduced runoff were the main water supplies for Nam Co lake and played a dominant role in the lake growth.

Figure 12 shows the time series of lake evaporation on Nam Co from different studies and models. Wu et al. (2014) used the Penman-Monteith model to calculated lake evaporation, which has been adjusted according to pan observation. Ma et al. (2016) employed the CRLE model, and the simulated evaporation values overall compare well with those of Wu et al. (2014) (Fig. 11). The two means were 632.3 and $655.5 \mathrm{~mm}$ for 1980 2010, respectively. By using the Flake model, Lazhu et al. (2016) got a mean annual evaporation of $832 \pm$ $69 \mathrm{~mm}$ for 1980-2014, and this value was much larger than that of Wu et al. (2014) and Ma et al. (2016). In this study, a one-layer water model was applied, and the calculated mean annual evaporation was $758.3 \mathrm{~mm}$ for 1979-2013, which was slight less than the result from
Lazhu et al. (2016) for 1980-2014. The temporal variability of evaporation from this study showed similar pattern with Lazhu et al. (2016), displaying an overall increasing trend.

As located in a high altitude $(>4700 \mathrm{~m})$ with a cold climate condition, Nam Co freezes during the cold season, and evaporation takes place in the form of sublimation. According to Ke et al. (2013), frozen period was sustained shortening for recent decades due to climate warming (Fig. 13a). On the contrary, ice-free period was extending, and it would help to evaporation. Along with rising temperature, the annual evaporation showed an increasing trend of $2.6 \mathrm{~mm} \mathrm{yr}^{-1}$ while the frozen duration showed a decreasing trend of -0.6 days $\mathrm{yr}^{-1}$ (Fig. 13a). The correlation coefficients between each other were $-0.608,0.701$, and -0.528 , respectively (Figs. 13b,c,d). The rising temperature led to increasing evaporation in two ways, one was providing an energy source for evaporation, and the second was extending the ice-free period. The increasing evaporation has a negative effect on the lake water storage. And this had mitigated the recent expansion of the lake. On the other hand, the rising temperature led to increasing glacier runoff into the lake. Hence, the rising temperature had two diametrically opposed effects of lake water balance.

Some factors may lead to uncertainties in lake water balance studies in the TP, such as the forcing data and the model, as well as other processes. As at high 


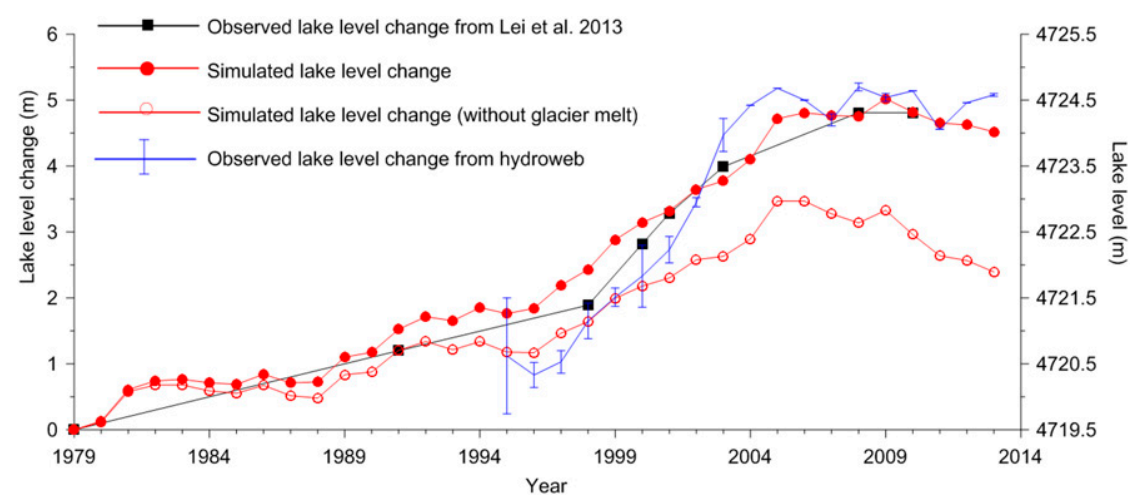

FIG. 11. Observed and simulated water level changes for Nam Co Lake during 1979-2013.

altitudes, the TP is covered by amounts of snow especially in the cold season ( $\mathrm{Li}$ et al. 2020). By comparing with in situ observations, Pu et al. (2007) evaluated the accuracy of MODIS snow data over the TP and suggested that the overall accuracy was about $90 \%$ during 2000-06. In this study, the simulated SCF by the VIC model showed some differences with the MODIS data. The performance of the VIC model is mainly dependent on meteorological input data. The uncertainties are unavoidable due to limited gauge observations involved in the ITPCAS forcing data in this region and may also from its downscaling processes. According to Zhang et al. (2013), snowmelt runoff contributed $20 \%-31 \%$ of total runoff among the source regions of six rivers in the TP. In this study, the simulated snowmelt runoff contributed $28 \%$ of the total runoff and is close to the result from Zhang et al. (2013). For the model calibration, 3 years (2006-08) of streamflow data and 2 years
(2012-13) of evaporation data were used, and this may also result in uncertainties. Under a warming climate, TP is experiencing permafrost degradation (Cheng and Wu 2007; Cheng and Jin 2013; Wu et al. 2012), and groundwater recharge and discharge rates are expected to increase, especially during winter (Peterson et al. 2002; Yang et al. 2002). Tong et al. (2016) analyzed winter flows (base flows) in the Siling Co Lake basin nearby during 1979-2013 by modeling. The increasing trends of the winter flows may be related to the melting of frozen soils in the basin, while the impacts of permafrost degradation may be minor.

\section{Conclusions}

In this study, a comprehensive hydrologic investigation was conducted in the Nam Co Lake basin during 1979-2013. Evapotranspiration from the land areas,

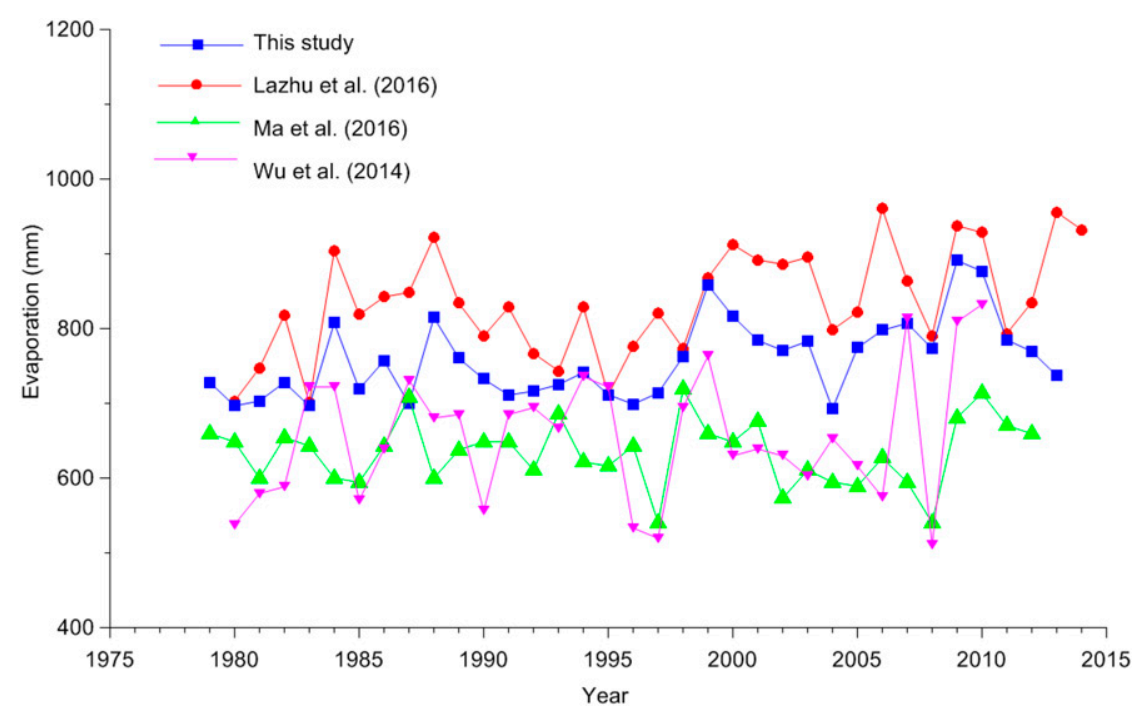

FIG. 12. Time series of lake evaporation on Nam Co from different studies. 

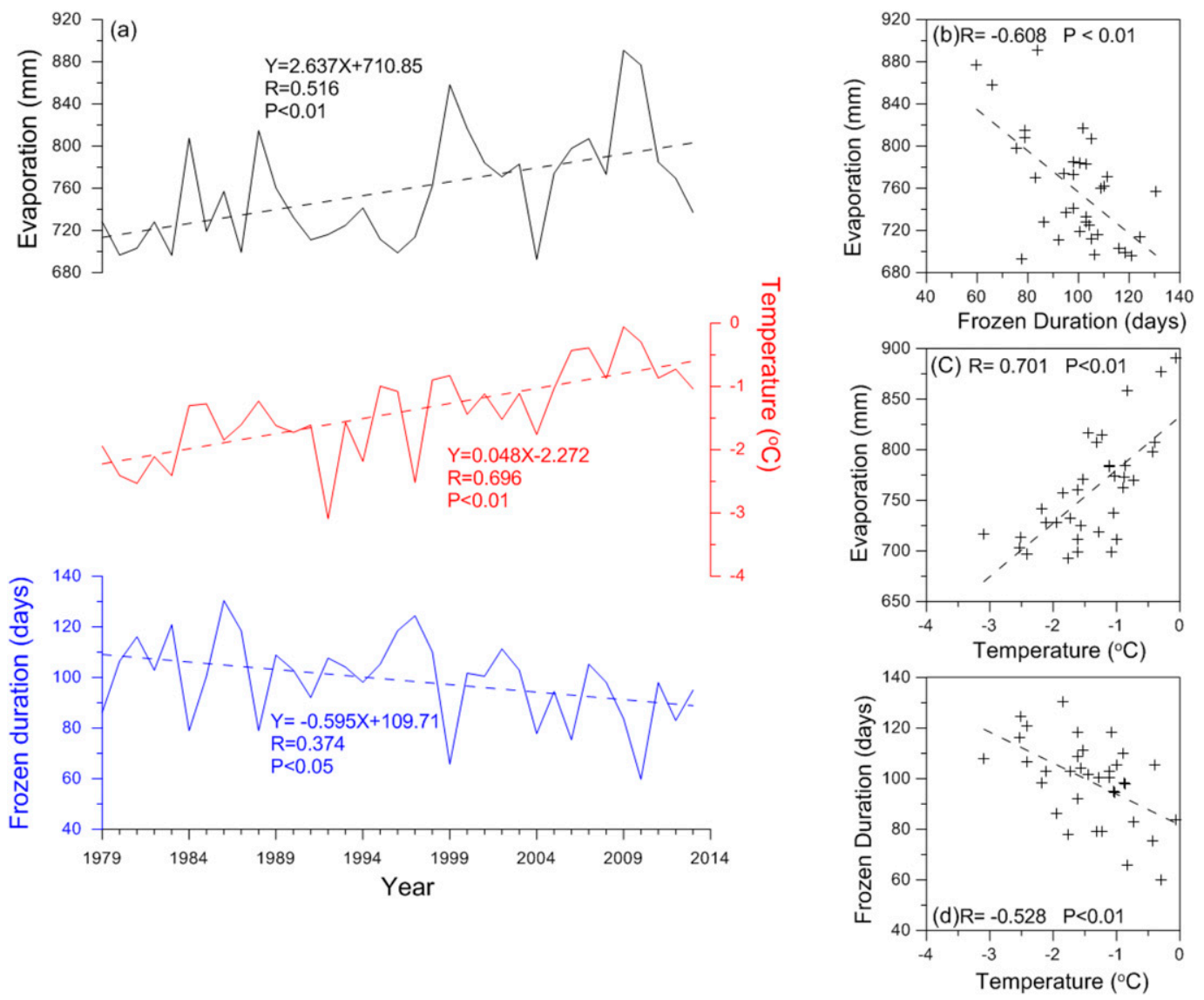

FIG. 13. Time series of lake surface evaporation, air temperature, and frozen duration, and scatterplots between them.

runoff from both glacierized and nonglacierized areas, and evaporation on the lake surface were continuously modeled during 1979-2013, and lake level changes were reconstructed. The main results are summarized as follows:

1) The mountain region in the southeastern basin was the main runoff-producing area. The land regions of the basin had a mean annual runoff of $107.6 \mathrm{~mm}$ during 1979-2013. Rainfall runoff, snowmelt runoff, and glacier runoff contributed $59 \%, 28 \%$, and $13 \%$ to the total runoff, respectively. For the high-altitude region (5500-6000, >6000 m), runoff was mostly generated from glaciers.

2) The lake had a positive net water budget in most of the years with an average lake level depth of $128.8 \mathrm{~mm}$, resulting in a total rise of approximately $4.5 \mathrm{~m}$. Precipitation and precipitation-induced runoff were the main water supplies of the lake and played a dominant role in lake growth. The decrease in lake expansion after 2004 is mainly due to runoff decrease. Although glacier runoff only contributed
$13 \%$ of the total runoff, it played an important role in controlling the water level.

3) The rising temperature led to increasing evaporation in two ways: providing an energy source for evaporation and extending the ice-free period. This mitigated the recent expansion of the lake. On the other hand, the rising temperature led to increasing glacier runoff into the lake. Hence, the rising temperature had two diametrically opposed effects on lake water balance.

Lake water balances are sensitive indicators of climate change in the TP. There are no sufficient in situ hydroclimate observations due to harsh natural conditions, which are the major challenges for water balance studies in this region. Remote sensing products have exhibited a great potential for providing high-resolution hydrological and geographical information in remote regions. In the future, more in situ and satellite observations are needed to decrease model uncertainties on investigating the hydrologic processes. Furthermore, lakes in other regions of the 
plateau with different change patterns should be investigated.

Acknowledgments. This work was supported by the National Natural Science Foundation of China (41701075, 41871057). The ITPCAS forcing dataset is provided by National Tibetan Plateau Data Center (http://data.tpdc.ac.cn). Meteorological data for 2006-08 from the Nam Co station, Monthly streamflow data were provided by the Third Pole Environmental (TPE) Database (http://www.tpedatabase.cn). Lake area and level change data from Lei et al. (2013) and the Hydroweb (http://hydroweb.theia-land.fr/hydroweb/). Landsat MSS images (https://search.earthdata.nasa.gov/ search) and MODIS snow cover data (https://nsidc.org/ data/MOD10C2/versions/6) were provided by NASA.

\section{REFERENCES}

Biskop, S., F. Maussion, P. Krause, and M. Fink, 2016: Differences in the water-balance components of four lakes in the southerncentral Tibetan Plateau. Hydrol. Earth Syst. Sci., 20, 209-225, https://doi.org/10.5194/hess-20-209-2016.

Bolch, T., T. Yao, S. Kang, M. F. Buchroithner, D. Scherer, F. Maussion, E. Huintjes, and C. Schneider, 2010: A glacier inventory for the western Nyainqêntanglha Range and the Nam Co basin, Tibet, and glacier changes 1976-2009. Cryosphere, 4, 419-433, https://doi.org/10.5194/tc-4-419-2010.

Chen, F., S. Kang, Y. Zhang, and Q. You, 2009: Glaciers and lake change in response to climate change in the Nam Co basin, Tibet (in Chinese). J. Mt. Sci., 27, 641-647.

Chen, Y., K. Yang, J. He, J. Qin, J. Shi, J. Du, and Q. He, 2011: Improving land surface temperature modeling for dry land of China. J. Geophys. Res., 116, D20104, https://doi.org/10.1029/ 2011JD015921.

Cheng, G., and T. Wu, 2007: Responses of permafrost to climate change and their environmental significance, Qinghai-Tibet Plateau. J. Geophys. Res., 112, F02S03, https://doi.org/10.1029/ 2006JF000631.

— Qinghai-Tibet Plateau and in northeast China. Hydrogeol. J., 21, 5-23, https://doi.org/10.1007/s10040-012-0927-2.

Cherkauer, K. A., and D. P. Lettenmaier, 1999: Hydrologic effects of frozen soils in the upper Mississippi River basin. J. Geophys. Res., 104, 19 599-19 610, https://doi.org/10.1029/ 1999JD900337.

— frozen soil. J. Geophys. Res., 108, 8858, https://doi.org/10.1029/ 2003JD003575.

Dai, Y., T. Yao, X. Li, and F. Ping, 2018: The impact of lake effects on the temporal and spatial distribution of precipitation in the Nam Co basin, Tibetan Plateau. Quat. Int. , 475, 63-69, https:// doi.org/10.1016/j.quaint.2016.01.075.

FAO/IIASA/ISRIC/ISSCAS/JRC, 2012: Harmonized World Soil Database (version 1.2). FAO and IIASA, http:// webarchive.iiasa.ac.at/Research/LUC/External-World-soil-database/ HTML/index.html?sb=1.

Gao, T., S. Kang, P. Krause, L. Cuo, and S. Nepal, 2012: A test of J2000 model in a glacierized catchment in the central Tibetan Plateau. Environ. Earth Sci., 65, 1651-1659, https://doi.org/ 10.1007/s12665-011-1142-5.
- - L. Cuo, T. Zhang, G. Zhang, and Y. Zhang, 2015: Simulation and analysis of glacier runoff and mass balance in the Nam Co basin, southern Tibetan Plateau. J. Glaciol., 61, 447-460, https://doi.org/10.3189/2015JoG14J170.

Hansen, M. C., R. S. DeFries, J. R. G. Townshend, and R. Sohlberg, 2000: Global land cover classification at $1 \mathrm{~km}$ spatial resolution using a classification tree approach. Int J. Remote Sens., 21, 1331-1364, https://doi.org/10.1080/ 014311600210209.

He, J., 2010: Development of a surface meteorological dataset of China with high temporal and spatial resolution (in Chinese). M.S. thesis, Institute of Tibetan Plateau Research, Chinese Academy of Science, $78 \mathrm{pp}$.

— K. Yang, W. Tang, H. Lu, J. Qin, Y. Chen, and X. Li, 2020: The first high-resolution meteorological forcing dataset for land process studies over China. Sci. Data, 7, 25, https://doi.org/10.1038/ s41597-020-0369-y.

Hock, R., 1999: A distributed temperature-index ice- and snow melt model including potential direct solar radiation. J. Glaciol., $\mathbf{4 5}$, 101-111, https://doi.org/10.3189/S0022143000003087.

_ 2003: Temperature index melt modelling in mountain areas. J. Hydrol., 282, 104-115, https://doi.org/10.1016/S0022-1694(03) 00257-9.

Immerzeel, W. W., L. P. H. Van Beek, and M. F. P. Bierkens, 2010: Climate change will affect the Asian water towers. Science, 328, 1382-1385, https://doi.org/10.1126/science.1183188.

Jarvis, A., H. I. Reuter, A. Nelson, and E. Guevara, 2008: Holefilled SRTM for the globe version 4. CGIAR-CSI SRTM $90 \mathrm{~m}$ Database, accessed 10 April 2020, https://cgiarcsi.community/data/ srtm-90m-digital-elevation-database-v4-1.

Kang, S., F. Chen, Q. Ye, Z. Jing, D. Qin, and J. Ren, 2007: Glacier retreating dramatically on the Mt. Nyainqêntanglha during the last 40 years (in Chinese). J. Glaciol. Geocryol., 28, 656-662.

Ke, C., A. Tao, and X. Jin, 2013: Variability in the ice phenology of Nam Co Lake in central Tibet from scanning multichannel microwave radiometer and special sensor microwaveimager 1978 to 2013. J. Appl. Remote Sens., 7, 073477, https://doi.org/ 10.1117/1.JRS.7.073477.

Kojima, K., 1979: Snowmelt mechanism and heat budget. Meteor. Study Notes, 146, 1-38.

Kondo, J., and T. Kuwagata, 1992: Hydrological climate in Japan (1): Radiation and evaporation from shallow lakes (in Japanese). J. Japan Soc. Hydrol. Water Res., 5, 13-27, https:// doi.org/10.3178/jjshwr.5.13.

Krause, P., S. Biskop, J. Helmschrot, W.-A. Flügel, S. Kang, and T. Gao, 2010: Hydrological system analysis and modeling of the Nam Co basin in Tibet. Adv. Geosci., 27, 29-36, https:// doi.org/10.5194/adgeo-27-29-2010.

Lazhu, K. Yang, J. Wang, Y. Lei, Y. Chen, L. Zhu, B. Ding, and J. Qin, 2016: Quantifying evaporation and its decadal change for Lake Nam Co, central Tibetan Plateau. J. Geophys. Res. Atmos., 121, 7578-7591, https://doi.org/10.1002/2015JD024523.

Lei, Y., T. Yao, C. Yi, W. Wang, Y. Sheng, and J. Li, 2012: Glacier mass loss induced the rapid growth of Linggo Co on the central Tibetan Plateau. J. Glaciol., 58, 177-184, https://doi.org/ 10.3189/2012JoG11J025.

- — - B. W. Bird, K. Yang, J. Zhai, and Y. Sheng, 2013: Coherent lake growth on the central Tibetan Plateau since the 1970s: Characterization and attribution. J. Hydrol., 483, 61-67, https://doi.org/10.1016/j.jhydrol.2013.01.003.

-, K. Yang, B. Wang, Y. Sheng, B. W. Bird, G. Zhang, and L. Tian, 2014: Response of inland lake dynamics over the 
Tibetan Plateau to climate change. Climatic Change, 125, 281290, https://doi.org/10.1007/s10584-014-1175-3.

Li, B., Z. Yu, Z. Liang, and K. Acharya, 2014: Hydrologic response of a high altitude glacierized basin in the central Tibetan Plateau. Global Planet. Change, 118, 69-84, https://doi.org/ 10.1016/j.gloplacha.2014.04.006.

Li, W., W. Guo, B. Qiu, Y. Xue, P. Hsu, and J. Wei, 2018: Influence of Tibetan Plateau snow cover on East Asian atmospheric circulation at medium-range time scales. Nat. Commun., 9, 4243, https://doi.org/10.1038/s41467-018-06762-5.

— B. Qiu, W. Guo, Z. Zhu, and P. Hsu, 2020: Intraseasonal variability of Tibetan Plateau snow cover. Int. J. Climatol., https://doi.org/10.1002/JOC.6407, in press.

Liang, X., D. P. Lettenmaier, E. F. Wood, and S. Burges, 1994: A simple hydrologically based model of land surface water and energy fluxes for general circulation models. J. Geophys. Res., 99, 14 415-14 428, https://doi.org/10.1029/94JD00483.

_ - E. F. Wood, and D. P. Lettenmaier, 1996: Surface soil moisture parameterization of the VIC-2 L model: Evaluation and modification. Global Planet. Change, 13, 195-206, https:// doi.org/10.1016/0921-8181(95)00046-1.

Liao, J., G. Shen, and Y. Li, 2013: Lake variations in response to climate change in the Tibetan Plateau in the past 40 years. Int. J. Digital Earth, 6, 534-549, https://doi.org/10.1080/ 17538947.2012.656290.

Liu, J., S. Kang, T. Gong, and A. Lu, 2010: Growth of a highelevation large inland lake, associated with climate change and permafrost degradation in Tibet. Hydrol. Earth Syst. Sci., 14, 481-489, https://doi.org/10.5194/hess-14-481-2010.

Lohmann, D., R. Nolte-Holube, and E. Raschke, 1996: A largescale horizontal routing model to be coupled to land surface parameterization schemes. Tellus, 48A, 708-721, https:// doi.org/10.1034/j.1600-0870.1996.t01-3-00009.x.

— E. Raschke, B. Nijssen, and D. P. Lettenmaier, 1998: Regional scale hydrology: I. Formulation of the VIC-2 L model coupled to a routing model. Hydrol. Sci. J., 43, 131-141, https://doi.org/10.1080/02626669809492107.

Lu, A., T. Yao, and L. Wang, 2005: Remote sensing research about typical glacier and lake variation in Qinghai-Tibet Plateau (in Chinese). J. Glaciol. Geocryol., 27, 783-792.

Lu, M., S. Zhou, and X. He, 2017: A comparison of the formulas for estimation of the lake evaporation on the Tibetan Plateau: Taking Nam Co as an example. J. Glaciol. Geocryol., 39, 281-291.

Ma, N., J. Szilagyi, G. Niu, Y. Zhang, T. Zhang, B. Wang, and Y. Wu, 2016: Evaporation variability of Nam Co Lake in the Tibetan Plateau and its role in recent rapid lake expansion. J. Hydrol., 537, 27-35, https://doi.org/10.1016/j.jhydrol.2016.03.030.

Ma, R., and Coauthors, 2011: China's lakes at present: Number, area and spatial distribution. Sci. China Earth Sci., 54, 283289, https://doi.org/10.1007/s11430-010-4052-6.

Meng, K., X. Shi, E. Wang, and F. Liu, 2012: High-altitude salt lake elevation changes and glacial ablation in Central Tibet, 20002010. Chin. Sci. Bull., 57, 525-534, https://doi.org/10.1007/ s11434-011-4849-5.

Myneni, R. B., R. R. Nemani, and S. W. Running, 1997: Estimation of global leaf area index and absorbed PAR using radiative transfer models. IEEE Trans. Geosci. Remote Sens., 35, 13801393, https://doi.org/10.1109/36.649788.

Peterson, B. J., R. M. Holmes, J. W. McClelland, C. J. Vorosmarty, R. B. Lammers, A. I. Shiklomanov, and S. Rahmstorf, 2002: Increasing river discharge to the Arctic Ocean. Science, 298, 2171-2173, https://doi.org/10.1126/science.1077445.
Pu, Z., L. Xu, and V. V. Salomonson, 2007: MODIS/Terra observed seasonal variations of snow cover over the Tibetan Plateau. Geophys. Res. Lett., 34, L06706, https://doi.org/ 10.1029/2007GL029262.

Qiu, J., 2008: China: The third pole. Nature, 454, 393-396, https:// doi.org/10.1038/454393a.

Shi, Y., 1990: Drying and warming trend of Middle Asia indicated by mountain glacier and lake shrinking and vision of the future (in Chinese). J. Geogr. Sci., 45, 1-13.

- 2001: Estimation of the water resources affected by climatic warming and glacier shrinkage before 2050 in west China (in Chinese). J. Glacial. Geocryol., 23, 333-341.

- 2005: Glacial Inventory of China (Synthesis Volume) (in Chinese). Science Popularization Press, 33-178.

Song, C., Q. Ye, and X. Chen, 2015: Shifts in water-level variation of Namco in the central Tibetan Plateau from ICESat and CryoSat-2 altimetry and station observations. Sci. Bull., 60, 1287-1297, https://doi.org/10.1007/s11434-015-0826-8.

Storck, P., and D. P. Lettenmaier, 1999: Predicting the effect of a forest canopy on ground snow accumulation and ablation in maritime climates. Proc. 67th Western Snow Conf., South Lake Tahoe, CA, Western Snow Conference, 12 pp., https:// westernsnowconference.org/node/308.

Tian, K., J. Liu, S. Kang, I. B. Campbell, F. Zhang, Q. Zhang, and W. Lu, 2009: Hydrothermal pattern of frozen soil in Nam Co lake basin, the Tibetan Plateau. Environ. Geol., 57, 1775-1784, https://doi.org/10.1007/s00254-008-1462-2.

Tong, K., F. Su, and B. Xu, 2016: Quantifying the contribution of glacier meltwater in the expansion of the largest lake in Tibet. J. Geophys. Res. Atmos., 121, 11 158-11 173, https://doi.org/ 10.1002/2016JD025424.

Wang, J., L. Zhu, G. Daut, J. Ju, X. Lin, Y. Wang, and X. Zhen, 2009: Investigation of bathymetry and water quality of Lake Nam Co, the largest lake on the central Tibetan Plateau, China. Limnology, 10, 149-158, https://doi.org/ 10.1007/s10201-009-0266-8.

Wu, Q., S. Kang, T. Gao, and Y. Zhang, 2010: The characteristics of the positive degree-day factors of the Zhadang Glacier on the Nyainqêntanglha range of Tibetan Plateau, and its application. J. Glacial. Geocryol., 32, 891-897.

_ T. Thang, and Y. Liu, 2012: Thermal state of the active layer and permafrost along the Qinghai-Xizang (Tibet) Railway from 2006 to 2010. Cryosphere, 6, 607-612, https://doi.org/ 10.5194/tc-6-607-2012.

Wu, Y., H. Zheng, B. Zhang, D. Chen, and L. Lei, 2014: Long-term changes of lake level and water budget in the Nam Co lake basin, central Tibetan Plateau. J. Hydrometeor., 15, 13121322, https://doi.org/10.1175/JHM-D-13-093.1.

$\mathrm{Xu}$, J., S. Yu, J. Liu, S. Haginoya, Y. Ishigooka, T. Kuwagata, M. Hara, and T. Yasunari, 2009: The implication of heat and water balance changes in a lake basin on the Tibetan Plateau. Hydrol. Res. Lett., 3, 1-5, https://doi.org/10.3178/hrl.3.1.

Yang, D., D. Kane, L. Hinzman, X. Zhang, T. Zhang, and H. Ye, 2002: Siberian Lena River hydrologic regime and recent change. J. Geophys. Res., 107, 4694, https://doi.org/10.1029/ 2002JD002542.

Yang, K., and J. He, 2018: China meteorological forcing dataset (19792018). National Tibetan Plateau Data Center, accessed 10 April 2020, https://doi.org/10.11888/AtmosphericPhysics.tpe.249369.file.

Yao, T., Y. Wang, S. Liu, J. Pu, Y. Shen, and A. Lu, 2004: Recent glacial retreat in High Asia in China and its impact on water resource in Northwest China. Sci. China. Ser., 47, 1065-1075, https://doi.org/10.1360/03yd0256. 
, J. Pu, A. Lu, Y. Wang, and W. Yu, 2007: Recent glacial retreat and its impact on hydrological processes on the Tibetan Plateau, China, and Surrounding Regions. Arct. Antarct. Alp. Res., 39, 642-650, https://doi.org/10.1657/1523-0430(07-510) [YAO]2.0.CO;2.

, Z. Li, W. Yang, X. Guo, L. Zhu, S. Kang, Y. Wu, and W. Yu, 2010: Glacial distribution and mass balance in the Yarlung Zangbo River and its influence on lakes. Chin. Sci. Bull., 55, 2072-2078, https://doi.org/10.1007/s11434-010-3213-5.

—- and Coauthors, 2012: Different glacier status with atmospheric circulations in Tibetan Plateau and surroundings. Nat. Climate Change, 2, 663-667, https://doi.org/10.1038/ nclimate1580.

Ye, Q., T. Yao, H. Zheng, and X. Zhang, 2008: Glacier and lake co2variations and their responses to climate change in the Mapam Yumco Basin on Tibet. Geogr. Res., 27, 1178-1190.

You, Q., S. Kang, K. Tian, J. Liu, and C. Li, 2007: Features of meteorological parameters at Nam Co station, Tibetan Plateau (in Chinese). Meteor. Mon., 33, 54-60.
Zhang, G., T. Yao, H. Xie, K. Kang, and F. Zhu, 2014a: Lakes' state and abundance across the Tibetan Plateau. Chin. Sci. Bull., 59, 3010-3021, https://doi.org/10.1007/s11434-014-0258-x.

_ - S. Kang, L. Cuo, and B. Qu, 2016: Modeling hydrological process in a glacier basin on the central Tibetan Plateau with a distributed hydrology soil vegetation model. J. Geophys. Res. Atmos., 121, 9521-9539, https://doi.org/10.1002/2016JD025434.

Zhang, L., F. Su, D. Yang, Z. Hao, and K. Tong, 2013: Discharge regime and simulation for the upstream of major rivers over Tibetan Plateau. J. Geophys. Res. Atmos., 118, 8500-8518, https://doi.org/10.1002/JGRD.50665.

Zhang, X., Y. Wu, and X. Zhang, 2014b: Water level variation of inland lakes on the south-central Tibetan Plateau in 1972-2012 (in Chinese). Acta Geogr. Sin., 69, 993-1001, https://doi.org/ 10.11821/DLXB201407011.

Zhu, L., M. Xie, and Y. Wu, 2010: Quantitative analysis of lake area variations and the influence factors from 1971 to 2004 in the Nam Co basin of the Tibetan Plateau. Chin. Sci. Bull., 55, 1294-1303, https://doi.org/10.1007/s11434-010-0015-8. 